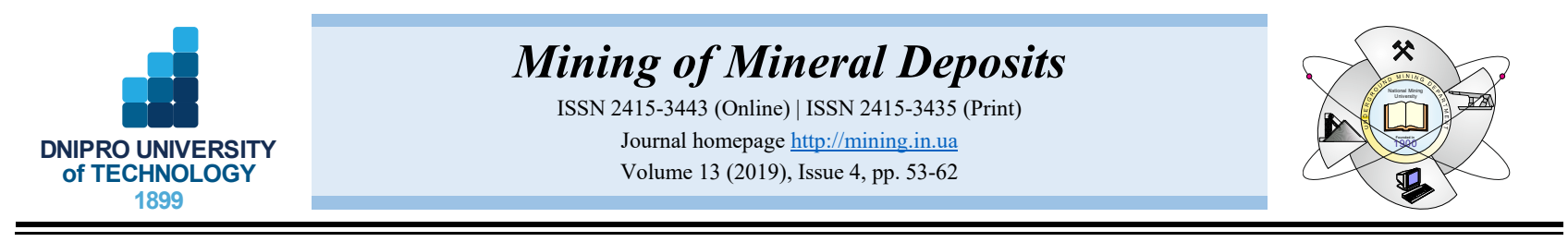

UDC 622.22.553.4:519.85

https://doi.org/10.33271/mining13.04.053

\title{
MODELS AND METHODS TO MAKE DECISIONS WHILE MINING PRODUCTION SCHEDULING
}

\author{
A. Khorolskyi ${ }^{*}$, V. Hrinov ${ }^{1}$, O. Mamaikin ${ }^{2}$, Yu. Demchenko ${ }^{2}$ \\ ${ }^{1}$ Institute for Physics of Mining Processes of the National Academy Sciences of Ukraine, Dnipro, Ukraine \\ ${ }^{2}$ Dnipro University of Technology, Dnipro, Ukraine \\ *Corresponding author: e-mail andreykh918@gmail.com, tel.+380952404007,fax:+3805624632826
}

\begin{abstract}
Purpose is to develop a new approach to the design of mining operations basing upon models and methods of decision making.

Methods. The paper has applied a complex approach involving approaches of decision-making theory. Analysis of the pro-duction development scenarios is proposed for strategic activity planning; criteria to make decisions under the uncertainty conditions as well as decision-making trees for day-to-day management are proposed to determine balanced production level.

Findings. It has been identified that mining production design is of the determined character demonstrating changes in "state of the nature" depending upon the made decisions. The idea of mining production is to reduce uncertainty gradually by means of analysis of production scenarios, and elimination of unfavourable alternatives. Operative management is implemented while constructing decision trees, and optimizing operation parameters. Representation of sets of rational equipment types as well as development scenarios, and their comparison in terms of decision-making parameters makes it possible to determine adequate capacity of a working area, and to reduce expenditures connected with the equipment purchase and maintenance. In this context, limiting factors, effecting anticipatory mining out-put, are taken into consideration. Successive comparison of the alternatives helps identify decision-making area for different scenarios of the production development.
\end{abstract}

Originality. To manage mining production, approaches of decision-making theory have been proposed which involve the use of decision trees, decision-making criteria, and analysis of scenarios basing upon representation of operating procedures in the form of a network model within which the shortest route corresponds to optimum decision.

Practical implications. Decision-making system has been developed making it possible to optimize operation parameters, to reduce prime cost of mining, and to select a structure of engineering connections with the specified production level. The described approaches may be applied at the stage of a stope design as well as in the process of a field development. Specific attention has been paid to a software development to implement the approaches.

Keywords: production, optimization, efficiency, software, criterion

\section{INTRODUCTION}

A process of mining design is a complex of interdependent engineering and economic tasks involving stages of equipment selection, substantiation of adequate production level as well as reduction of expenditures connected with purchase and maintenance of mechanical aids (Hrinov \& Khorolskyi, 2018). Optimum decision making is possible if only mandatory successful problem solving takes place at each previous stage. High requirements for engineering and operational production level can be explained by the determinate nature of formation of operation schedules as well as variety of states of "nature". Namely, depending upon functioning conditions of one or another alternative use, it helps obtain different results (i.e. "advantage"). Mining production management needs solving a number of problems which can be divided into conceptual problems (i.e. strategic), technical and technological problems, and those connected with human factor (Vagonova \& Volosheniuk, 2012; Gorova, Pavlychenko, Borysovs'ka, \& Krups'ka, 2013; Khomenko, Kononenko, Myronova, \& Sudakov, 2018).

The paper describes practices of decision-making theory use to solve problems belonging to each of the types. The idea is as follows: mining production design process is a "game with nature"; i.e. probability of origi-

(C) 2019. A. Khorolskyi, V. Hrinov, O. Mamaikin, Yu. Demchenko. Published by the Dnipro University of Technology on behalf of Mining of Mineral Deposits. This is an Open Access article distributed under the terms of the Creative Commons Attribution License (http://creativecommons.org/licenses/by/4.0/), which permits unrestricted reuse, distribution, and reproduction in any medium, provided the original work is properly cited. 
nation of one or another state of nature is not unknown at a design stage. "Rationalization" logic is: high production investment is inexpedient if probability of a successful scenario is minor. At the same time, it is possible to select a production scenario with the least risks only by means of uncertainty decrease.

Each problem solving has its own application area. Failure in the design of mining operation schedule will affect prime cost of output (Petlovanyi, Lozynskyi, Saik, $\&$ Sai, 2018) as well infrastructure of the region where the enterprise is located (Kalybekov, Rysbekov, Toktarov, \& Otarbaev, 2019; Kalybekov, Sandibekov, Rysbekov, \& Zhakypbek, 2019). Hence, it is strategic problem being solved by means of construction of production scenarios, their intertemporal and spatial comparison, and selection of a sole optimum (Pivnyak, Dychkovskyi, Smirnov, \& Cherednichenko, 2013; Bondarenko, Kovalevs'ka, \& Ganushevych, 2014).

Special attention should also be given to the equipment selection since economic characteristics are available in addition to engineering characteristics and operational ones. Any enterprise can become unprofitable if equipment with high technical data is applied but expenditures connected with its purchase many times exceed prices for its domestic analogues (Khomenko, Kononenko, \& Lyashenko, 2019). Thus, the problem is two-sided: first, it can be explained by a non-use of the equipment potential when mining and geological conditions prevent from its complete application; second, by high expenditures connected with its purchase and maintenance. Hence, "rational" equipment is that one involved maximally under the specified mining and geological conditions when prime cost of mining is minimal rather than the equipment which efficiency is the highest. Decision-making criteria under uncertainty conditions should be applied to solve technical and technological problems. The criteria may help draw conclusions concerning the expediency of some or other equipment use.

Moreover, there are problems of operative management when a manager is engaged in regular decision making as for equipment purchase, implementation of control etc. Decision-making trees may be used to solve such problems.

Nevertheless, despite their reasonableness, fails in the listed approaches are similar to those belonging to methods of linear programming, analysis of hierarchies etc., i.e. high dimensionality, availability of basic and additional constructions, and complexity of interpretation of result. So, it is required to design adequate software to avoid the disadvantages.

Thus, use of decision-making theory methods to manage mining production as well as software development is topical scientific and practical task.

Currently, criteria evaluation method (Petlovanyi \& Medianyk, 2018), multi-criteria optimization method (Goodfellow \& Dimitrakopoulos, 2017), methods of linear programming (Rahal, Smith, Van Hout, \& Von Johannides, 2003), quadratic programming (Li, Tan, Yan, \& Deng, 2011), and dynamic programming (Yu \& Gao, 2016) are available to manage mining production. Each of them has its advantages and disadvantages.
Criteria evaluation method answer unambiguously (Kazakidis, 2010; Hoseinie, 2011) the question "Which of the alternatives is the best"; however, it is the best from the viewpoint of one parameter. It is not a fact that the parameter to be optimized is the most important parameter. Moreover, the models, relying upon parameters, are static ones; thus, they cannot be used for long-term planning.

Analytical hierarchical process (AHP) (Ataei, Jamshidi, Sereshki, \& Jalali, 2008; Iphar \& Alpay, 2018); metpethod of exclusion and selection (Mahase, Musingwini, \& Nhleko, 2016); and organization of a priority rank to upgrade evaluation PROMETHEE (Bogdanovic, Nikolic, \& Ilic, 2012) are the most popular today. The methods help determine "the most important" parameter. However, the problem is that advantages of one parameter over another are determined by a designer; i.e. there is a problem of subjectivity of opinions. Moreover, advantage degree of one parameter over another cannot be accommodated in the standard rating 1 to 7 scale. For instance, Donbas stopes apply equipment providing $500-3200$ t/day efficiency (Sotskov, Podvyhina, Dereviahina, \& Malashkevych, 2018).

Then, $3200 \mathrm{t} /$ day efficiency will correspond to $\varepsilon=1.0$ maximum advantage; $1100-1500 \mathrm{t} /$ day will correspond to a significant advantage level. The significant advantage $\varepsilon=0.5$ is understood as $10-50 \%$ efficiency surplus from minimum required $Q_{\min }$ in terms of breakeven operation of a mine. In the context of Donbas mines, $Q_{\min }=1000 \mathrm{t} /$ day (Salli, Pochepov, \& Mamaykin, 2014). As of the turn of 2014, 198 stopes functioned in Ukraine. Their efficiency was $500-3200 \mathrm{t} /$ day. In this context, distribution is not objective; only 5 per cent of the equipment (i.e. 10 stopes of 198) will correspond to maximum advantage level $\varepsilon=1.0$ and 37 per cent (i.e. 73 stopes of 198) will correspond to a significant advantage level. Namely, starting comparison stage demonstrates "warped" understanding of the advantage level. As of the turn of 2018, 75 stopes functioned in Ukraine. In this context, $3200 \mathrm{t}$ /day efficiency was observed in 4 stopes (i.e. 5 per cent); $1100-1500$ t/day efficiency was observed in 32 per cent of the stopes (i.e. 25 of 78). Hence, the ratio remained stable during the four years (Mamaikin, Sotskov, Demchenko, \& Prykhorchuk, 2018). How else can be evaluated higher engineering level of the equipment?

Methods of quadratic programming (Wang, Tu, Zhang, Yang, \& Tu, 2015), linear programming (Vujić et al., 2011), and dynamic programming are worth noticing. While analyzing operations, such a term as "programming" means a process of search for optimum actions and decisions i.e. search for a sequence with the least optimization parameter value. That can be achieved by means of more complex tasks fragmentation into simpler ones. Versatility, visualization, and possibility to study the processes in time are advantages of the method. However, attention should be paid to interpretation of the results, and software development.

Hence, the process of mining management is rather complex. It needs the use of universal tools, and models among which are graphs and network models. At a planning stage, application of graphs and networks helps analyze production scenarios; at a design stage, they help 
minimize uncertainty and risks; and at a stage of operative management they help reduce prime cost.

The listed approaches may be used by mining industry as well as the related production branches.

\section{STATEMENT OF THE PROBLEM}

The process of mining management involves search for several target functions. First, it is necessary to minimize prime cost of the finished product; second, it is necessary to minimize payback period. In this context, the functions are influenced by operation parameters of scheme $P_{T}$, mechanization level $P_{M}$, being determined by means of mining, transportation, mineral preparation etc., as well as $P_{E}$ expenditures connected with purchase, maintenance, and fund service.

The parameters are represented by a decision vector $P$ being within three-dimensional space $X$ of optional versions. In this context, the vector $P$ length is influenced by a decision-making process as well as by probability of one or another origination of production scenario $\varsigma$ characterized by $\alpha-\beta-\gamma$ ratio (i.e. completely negative results-intermediate results-completely successful results).

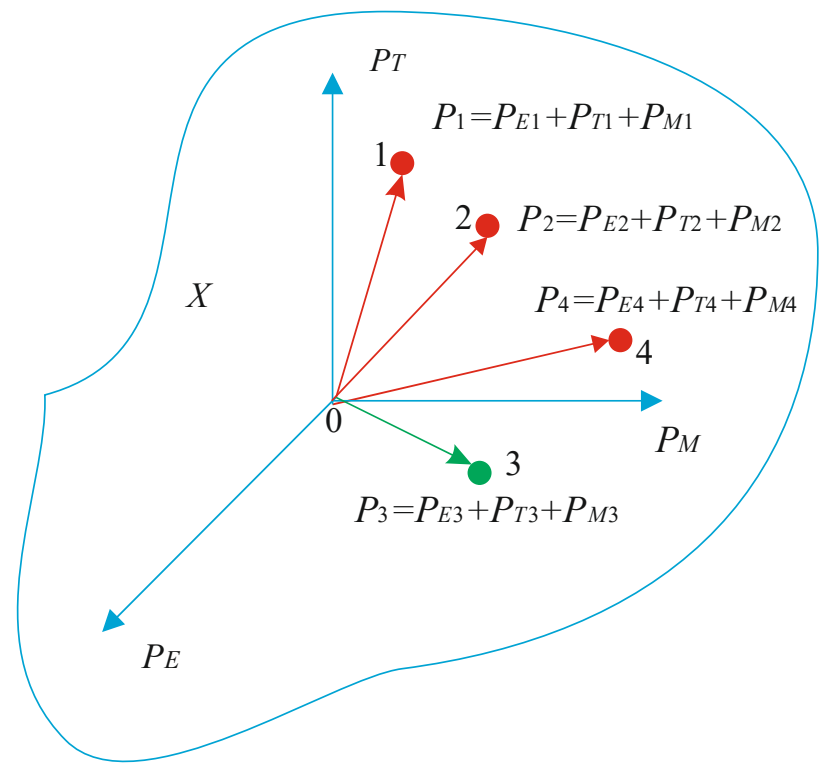

Figure 1. Area of possible results in the process of production design

Hence, the search for optimum decision involves minimization of a decision vector $P \rightarrow$ min within $X=f(\varsigma)$; $\varsigma=\alpha+\beta+\gamma=1$ space of optional versions. In this context, the problem is being solved two directionally:

- the selected option should be optimal from the viewpoint of cost minimization: $P \rightarrow \min \left(P_{T}, P_{M}, P_{E}\right)$;

- the selected option should guarantee the mentioned production level while minimizing production risks; i.e. in terms of the state of "nature", characterized by a probability of $\varsigma=\alpha+\beta+\gamma=1$ scenarios maximally efficient alternative should be adopted.

Then, optimum decision should involve minimization of prime cost of mineral mining in turn factoring into the reduced pay-off periods of production assets. That can be achieved owing to the uncertainty decrease making it possible to continue with assessment of production risks.
All that helps select the most optimum production scenario for the specified mining and geological conditions, market structure, and the deposit state.

\section{RESEARCH METHODS}

Thus, the purpose is to develop approaches to optimize parameters of deposit development relying upon decision-making theory methods. The idea is to apply decision-making trees, to analyze scenarios of production development as well as decision-making criteria under the uncertainty conditions to search for optimum alternatives. Universal graphs and network models have been used to solve the problems. Specific attention has been paid to software development.

As it has been mentioned, strategic planning of mining involves problems of reduction of prime cost as well as pay-off periods.

Target function of prime cost reduction can be expressed as follows:

$$
\begin{gathered}
\overline{C_{i}}=\frac{\sum_{t=1}^{T} D_{i t} C_{i t}}{\sum_{t=1}^{T} D_{i t}} \rightarrow \min ; i=\overline{1, n} ; \\
\left|\overline{C_{i+1}}-\overline{C_{i}}\right| \geq 0.01 \overline{C_{i}} ; i=\overline{1, n},
\end{gathered}
$$

where:

$\overline{C_{i}}$ and $C_{i t}$-average prime cost in terms of $i^{\text {th }}$ option per accounting period, and prime cost of a ton of end coal product in terms of $I^{\text {th }}$ option during $t$ year respectively;

$D_{i t}$ - mining output in terms of $I^{\text {th }}$ option during $t$ year;

$t$ and $T$-current year of an accounting period, and the accounting period.

Target function of pay-off period reduction is:

$$
\begin{aligned}
& T_{i} \rightarrow \min , i=\overline{1, n} ; \\
& T_{i}=\frac{\Delta S_{i}}{\Delta C_{i}}, i=\overline{1, n} ;
\end{aligned}
$$

$$
T_{i+1}-T_{i} \geq 0.01 T_{i}, i=\overline{1, n},
$$

where:

$\Delta S_{i}$ - additional capital investment in terms of $i^{\text {th }}$ option; $\Delta C_{i}$ - the current cost avoidance in terms of $i^{\text {th }}$ option.

A value of permissible error involves different viewpoints. Taking into consideration multidirectional nature of the errors which actual value remains unknown as well as possibilities of rather accurate calculations, it has been accepted that the options will vary where difference in values of target functions is more than 1 per cent. The models record the fact (formulas (2), and (5). The most complicated thing is to determine dependence functions of mining prime cost, and influx of funds in terms of the specific context of the planned option of a mine development. Each option of a mine development involves a set of actions with the help of which the object view can be achieved. The set identifies the required capital in- 
vestment, and forms prime cost in the context of models for $i^{\text {th }}$ options during $t$ year.

Then, to analyze production scenarios, "life" cycle of the enterprise including mining stages, transportation, and mineral processing should be represented in the form of a network model (Fig. 2).

(a)

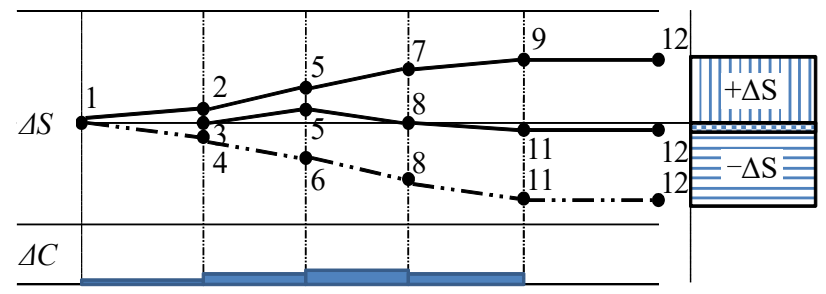

(b)

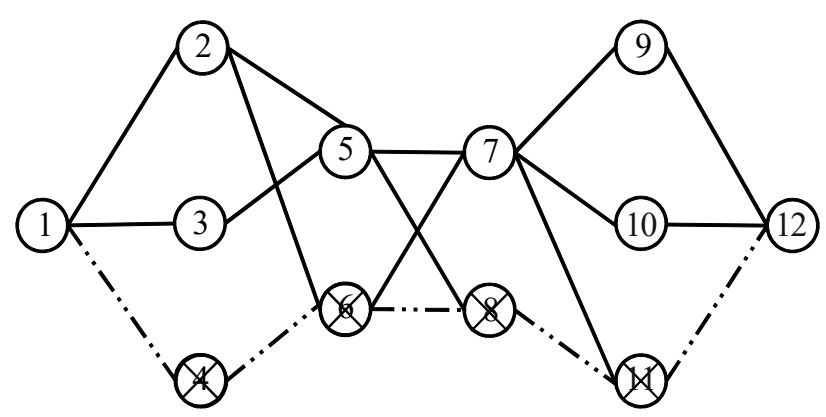

Figure 2. Changes in prime cost of mining: (a) graphs of changes in capital cost; (b) network models demonstrating various production scenarios

Figure 2 represents a lifecycle of an enterprise which development may take place according to three scenarios. Scenario 1: at each production stage a designer makes optimum decision which is the use of adequate solutions. Points 2, 5, 7, and 9 correspond to successful solutions. As a result, each stage records increment in profit $\Delta S$ taking place owing to changes in prime cost $\Delta C$. If so, then the route within a network model, passing through points $1-2-5-7-9-12$, will be optimum one.

Scenario 2: at each production stage, decisions are made relying upon practice or intuitively. In terms of such an approach, rational decisions (point 5), irrational decisions (points 8 and 11), and moderate decisions (point 10) are made. Even $\Delta S$ profits are possible owing to $\Delta C$ prime cost reduction. However, economic loss will always be at the end of the cycle $-\Delta S$ resulting from the decreased prime cost $-\Delta C$.

Scenario 3: incorrect decision is made at each stage. In terms of such an approach, loss is similar to profit according to scenario 1; however, it is opposite in sign. That can be explained by constant increase in prime cost of mining.

No matter which of the approaches is applied, there is a versatile order of steps to optimize operation schedules:

- first, it is required to demonstrate such an operation schedule which contains production cycle in the form of a network model; vertices are equipment types, technological types etc.; i.e. options are possible. Values of optimization parameter may be taken as a distance (edges) between vortices;
- to arrive at optimum solution, it is necessary to determine the shortest route within the network model.

Network and graph optimization algorithms may be applied to identify optimum route.

In this context, compelling stand of the authors is as follows: coal is not the end product; it is just intermediate link within coal-coke-metal system or coal-electrical energy system. Moreover, the system also involves preparation plants being, together with mines, the product manufacturers and consumers. Then, the required optimum condition may be described with the help of following model:

$$
\left.\begin{array}{c}
a_{i}^{\prime} \leq \sum_{j=1}^{n} x_{i j} \leq a_{j}^{\prime \prime}(i=1,2, \ldots, m) \\
\sum_{i=1}^{m} x_{i j}=b_{j}(j=1,2, \ldots, n)
\end{array}\right\} ;
$$

$$
\sum_{i=1}^{m} a_{i}^{\prime \prime}=\sum_{j=1}^{n} b_{j} \geq \sum_{i=1}^{m} a_{i}^{\prime},
$$

where:

$$
a_{i}^{\prime}, a_{i}^{\prime \prime}-\text { values of lower production capacity, and up- }
$$
per one;

$x_{i j}$ - the number of product units to be delivered from point $i$ to point $j$;

$b_{j}-$ the stipulated consumption in $j^{\text {th }}$ points.

Hence, cost minimization should involve constant coal demand as well as minimal expenditures connected with mining, and transportation which can be achieved at the expense of determination of rational output level.

Therefore, target function $c$ is expressed as follows:

$c=\sum_{i=1}^{m} \sum_{j=1}^{n} S_{i j} x_{i j} \rightarrow \min$,

where:

$S_{i j}$ - expenditures connected with coal extraction and transportation from a mining point to a consuming point.

Thus, each stage of mining management should involve minimization of expenditures connected with production as well as solving problems aimed at the determination of rational output which will help minimize risks.

Substantiation of application area of decision-making criteria use for the specified mining and geological conditions will make it possible to select operation schedule with minimum loss under unfavourable conditions and maximum profit.

\section{RESULTS AND DISCUSSION}

Hence, selection of rational output for the specified operation schedule is a "game with nature" when probability of a favourable scenario and an unfavourable one is unknown. On the one hand, there are options; on the other hand, there is uncertainty. The decreased uncertainty helps minimize risks. We have to select such a production level when an unfavourable scenario is lossless and a favourable scenario results in the maximum profits.

Introduce following specifications:

An alternative $X$ is an operation schedule including equipment or options of techniques. State of nature $M$ is a set of events resulting in the adequate effect. Thus, the set of favourable, unfavourable, and intermediate proba- 
bilities identifies state of nature. Our research considers options of totally unfavourable conditions when failure probability is maximal; totally favourable when success probability is maximal; and intermediate results when success probability $\varsigma$ is $0.1-0.9$.

Success is a profit value $R$ of a loss value $S$ which will be obtained while applying an alternative $X$ during the moment of state of nature $M$.

A pessimist is a decision maker (DM) relying upon the idea that success probability $\varsigma$ is less than 0.5 ; thus, the option helping minimize loss will be optimal one.

An optimist is a DM relying upon the idea that success probability $\varsigma$ is more than 0.5 ; thus, the option helping maximize profits is optimal one.

Our research considers Wald, "maximax", Laplace, Savage, and Hurwitz criteria as well as the generalized Hurwitz criterion.

Each criterion has its own application area; it is based upon risk attitude of DM. If innovative decision or solution is meant when implementation expediency of a new method is analyzed, then optimistic approach will be more feasible since income deficiency may affect the whole further process. If it is required to support available production capacities, then pessimistic approach is more reasonable.

Optimal operation schedule $X^{*}$ under uncertainty conditions is searched on the basis of comparison criteria of $X_{1}{ }^{*}, X_{2}{ }^{*}, \ldots, X_{i}^{*}$ options where $i=1,2, \ldots, N$ is a definition number of a schedule. Use of each of the criteria helps formulate a hypothesis concerning alternative "success" in terms of the known state of nature $M$. In other words, there are options providing $Q_{1}, Q_{2}, \ldots, Q_{i}$ extraction. In this context, expenditures connected with purchase and maintenance are $R_{1}, R_{2}, \ldots, R_{i}$ respectively and success is $X_{11}, X_{21}, \ldots, X_{i j}$ in terms of different states of nature $M=1,2, \ldots, j$.

It becomes understood that $X_{i j}{ }^{*}$ option is optimal one where success will be maximal (i.e. $X_{i j}$ ) in terms of the specified state of nature $M$. Each of the criteria makes it possible to assess different concepts of enterprise activity. Probability of $X_{i j}$ success for various production scenarios $M=1,2, \ldots, j$ may be represented as a "game" matrix:

$$
\begin{array}{cccc}
X_{11} & X_{12} & \cdots & X_{1 j} \\
X_{12} & X_{22} & \ldots & X_{2 j} \\
\cdots & \ldots & \ldots & \cdots \\
X_{i 1} & X_{i 2} & \cdots & X_{i j}
\end{array}
$$

If production process has not been started yet, then success value is equal to production cost, i.e. $X_{11}=R_{11}$; $X_{12}=R_{12}$; and $X_{i j}=R_{i j}$.

Then, selection of a rational production scenario is to select an option for each state of nature. In this context, the system state may be characterized by different development scenarios: $\alpha$-objective probability to obtain negative results; $\beta$-intermediate results; and $\gamma$ - probability of total success. The set of all probabilities is $\varsigma=\alpha+\beta+\gamma=1$, or:

$\varsigma=\alpha \frac{\sum P}{m}+\beta \frac{\sum I}{n}+\gamma \frac{\sum S}{p}$, where:

$\Sigma P-$ set of negative results;

$\Sigma I-$ set of intermediate results;

$\Sigma S$ - set of positive results;

$m, n$ and $p-$ the number of negative, intermediate, and positive results respectively.

Pair-wise comparison of options in terms of pair-wise assessments $(\alpha ; \gamma)$ helps obtain the most reasonable strategy at each stage (Fig. 3).

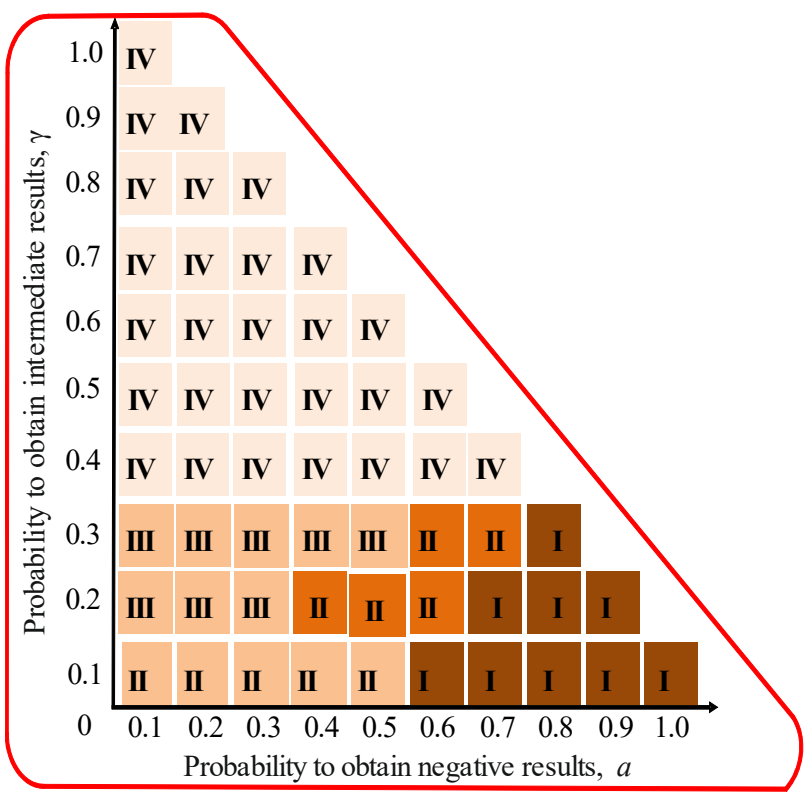

Figure 3. Distribution of the most successful decisions

Figure 3 may admit an assumption that if probability of success achievement is comparatively large (i.e. $\gamma \geq 0.3$ ), and probability of negative results is not more than $\alpha \leq 0.7$, it becomes possible to select an option with a potential tending to the increased extraction $Q \rightarrow \max$; conventionally, it is IV group. If probability of negative results is high (i.e. $\alpha \rightarrow 0$ ), it is worth selecting an option with $Q \equiv Q_{E}$ efficiency indices being equal to efficiency level a $Q_{E}$; conventionally, it is I group. Intermediate groups II and III are also available.

Use of the listed criteria makes it possible to calculate success value $X_{i j}$. Hence, it is necessary to consider each criterion in more detail and explain their calculation technique.

In the context of Wald criterion, an optimal option is that one providing the best success among possible ones if course of events is negative $(\gamma=0 ; \alpha=1)$, i.e. "minimax" - minimal losses:

$W_{i j}=\min \left(X_{i j}\right), j=1,2, \ldots M$.

It is expedient to apply Wald criterion (Nickel, Knight, Langille, \& Godwin, 2019) while calculating production risks for coal mines with unfavourable mining and geological conditions. At the stage of mining completion, and in terms of lack of investment, it is impossible to develop new operation schedules without taking into consideration the criterion.

"Maximax" criterion (Taneja, Ligteringen, \& Walker, 2012) is opposite to Wald criterion; i.e. success probabil- 
ity is high $-\gamma=1 ; \alpha=0$. According to the criterion, the alternative, capable of providing peak success, is optimal one. Similarly to Wald criterion, there will be two stages: stage one is search of maximal success for each option:

$$
\begin{aligned}
& M_{1}=\max \left(X_{1 j}\right), j=1,2, \ldots, 4 \Rightarrow \\
& M_{1}=\max \left(X_{11}, X_{12}, X_{13}, X_{14}\right)
\end{aligned},
$$

to be analogously for $M_{2}, M_{3}$ and $M_{4}$ as well.

Stage two is search for maximal option among $M_{1}$, $M_{2}, M_{3}$ and $M_{4}$, i.e.:

$$
X^{*}=M_{i j}=\max \left(M_{1}, M_{2}, M_{3}, M_{4}\right) .
$$

"Maximax" criterion is applicable if mining and geological conditions are favourable; there are no limitations in terms of a gas factor and operation mode of a coal shearer; and capacity of transportation chain is sufficient. The criterion should be applied for mines engaged in extraction of deficit coal grades owing to a peak demand.

Laplace criterion relies upon the principle of insufficient relevancy; i.e. an option with maximal average success will be optimal one. Therefore, success probability is $\gamma=1 / M=0.25$ for four states of nature $M=1 \ldots 4$. Then, in the context of stage one identify average successes $L_{1} \ldots L_{4}$ according to the formula:

$$
L_{i}=\frac{\sum_{j=1}^{M} X_{i j}}{M},
$$

and in the context of stage two identify maximal success among average ones $X^{*}=L_{i j}=\max \left(L_{1}, L_{2}, L_{3}, L_{4}\right)$.

Laplace criterion (Schniederjans, Hamaker, \& Schniederjans, 2010) can be applied in the context of long-term production planning as well as in the context of situations when design capacity of a stope is sufficient for its operation during several years.

It goes without saying that designers may face problems in the process of analyzing options according to the three criteria. Even greater difficulties arise when analysis according to Wald criterion $(\alpha=1, \gamma=0)$ and maxi$\max M_{i j}(\alpha=0, \gamma=1)$ give rise to absolutely opposite results. Relying upon long-term monitoring practice of activities by coal-mining enterprises and forecasting of operation indices, authors of the paper propose versatile approach based upon the use of the weighted criterion taking into consideration both positive and negative predictions. In this context, it is believed that probability of favourable scenario is $\gamma=2 / 5$; and probability of an unfavourable scenario is $\alpha=3 / 5$. Then, the weighted success value is:

$$
P_{i j}=\frac{3 W_{i j}+2 M_{i j}}{5} \text {. }
$$

Former criteria took into consideration successes. However, risks should also be involved. In our case, risks depend upon less profit. Apply Savage criterion to do that (Tulabandhula \& Rudin, 2013).

Savage criterion relies upon the idea that the option is optimal where the less success value will be minimal one; i.e. the lesser difference between less success $R_{i j}$ and real $X_{i j}$ is the better. The criterion relies upon risk matrix rather than upon game matrix. Thus, it involves three stages. Stage one is the search for maximal success value $Y_{i j}$; i.e. $Y_{1}=\max \left(X_{11}, X_{12}, X_{13}, X_{14}\right)$. Similar procedure is for $Y_{2}, Y_{3}$ and $Y_{4}$. Stage two is to determine maximal loss success $R_{i j}$ (i.e. $R_{11}=Y_{1}-X_{11}, R_{12}=Y_{2}-X_{12}, R_{13}=Y_{3}-X_{13}$, $\left.R_{14}=Y_{4}-X_{14}\right)$ for each state of nature $M=1 \ldots 4$. Stage three is to identify maximal loss profit for each chain, and to compare the options:

$$
\begin{aligned}
S_{i j} & =\max \left(R_{i j}\right), j=1,2, \ldots, M \\
X^{*} & =\min \left(S_{i j}\right), i=1,2, \ldots, N ; j=1,2, \ldots, M
\end{aligned} .
$$

Savage criterion should be applied at the initial design stage or when data concerning potential of the mining complex and production risks are not available. Such an approach is rather logical since value of actual mining will be equal to design characteristics of the mining complex. It is possible to say that if $S_{i j}-X_{i j}=0$ then resource balance is achieved; i.e. at minimal expenditures the complex will provide the planned design characteristics.

Hurwitz criterion (Sant'Anna, 2015) relies upon consideration of boundary system states through the use of coefficient of optimism, i.e. $0 \leq \lambda \leq 1$. When $\lambda=0$, the criterion becomes identical to Wald criterion; when $\lambda=1$, it becomes identical to maximax criterion. To compare with other criteria, it takes into consideration only maximum $X_{i \max }$ successes, and minimum $X_{i \min }$ ones. In other words:

$$
\begin{aligned}
& H_{i j}(\lambda)=\lambda X_{i j \max }+(1-\lambda) X_{i j \min } \\
& i=1,2, \ldots, N ; j=1,2, \ldots, M \\
& X^{*}=\max \left(H_{i j}(\lambda)\right), i=1,2, \ldots, N ; j=1,2, \ldots, M
\end{aligned}
$$

It is expedient to use the criterion when there is no practice of the equipment option use at an enterprise. Risk attitude of a designer is rather important too, i.e. if $\lambda \leq 0.4$ then option with less loss is optimal one, and if $\lambda \geq 0.4$ then option with maximal success is optimal.

The generalized Hurwitz criterion (Nachbaur \& Rohmer, 2011) resembles previous criterion; however, to compare with normal Hurwitz criterion, it calculates the weighted success values, i.e. each state of nature $M=1,2, \ldots, j$ has $\lambda_{q}$ probability. Then, in terms of $i^{\text {th }}$ option, success value will be as follows:

$H_{i}^{\prime}=\sum_{q=1}^{M} \lambda_{q} x_{i q}$,

where:

$0 \leq \lambda \leq 1$ is a coefficient for $q$ value of option $i$; nevertheless, $q$ probability of one or another state of nature should not be more than 1:

$$
\sum_{q=1}^{M} \lambda_{q}=1 \Rightarrow \lambda_{1}+\lambda_{2}+\ldots+\lambda_{q}=1 .
$$

Optimal option search procedure involves several stages. Stage one is to arrange state matrix $X$ by increase, i.e.

$x_{i 1}, x_{i 2}, \ldots, x_{i j} \rightarrow y_{i 1} \leq y_{i 2} \leq \ldots \leq y_{i j}, j=1,2, \ldots, M$. 
Stage two is to sum up all the successes in terms of each state of matrix $Y$ :

$y_{q}=\sum_{i=1}^{N} y_{i q}$.

Stage three is to calculate total of all successes if matrix $Y$ :

$y_{q}=\sum_{i=1}^{N} \sum_{q=1}^{M} y_{i q}=\sum_{q=1}^{M} y_{q}$.

Stage four is to determine attitude of a designer to the target function if it is necessary to search an option with maximal success (i.e. optimistic approach is meant), then $\lambda_{q}$ coefficient for any $q$ state will be:

$$
\lambda_{q}=\frac{y_{q}}{y} \Rightarrow \frac{y_{q}}{\sum_{q=1}^{M} y_{q}} .
$$

Therefore, greater coefficient belongs to the production scenario where maximal success is achieved. Otherwise, if it is required to minimize loss (i.e. pessimistic approach) in the context of a production development scenario when the worst results are expected, greater coefficient should be specified, i.e.:

$$
\lambda_{q}=\frac{y_{N-q+1}}{y} \Rightarrow \frac{y_{N-q+1}}{\sum_{q=1}^{M} y_{q}} .
$$

If so, then an option with maximal value of the generalized Hurwitz criterion will be optimal one:

$$
X^{*}=H_{i j}=\max \left(H_{i}^{\prime}\right), i=1,2, \ldots, N
$$

In the majority of cases, the criterion helps obtain identical solutions both for pessimistic and optimistic scenario of a production development since the state matrix is ordered in a highly reliable manner. Thus, it the assumption may be admitted that one or another scenario of a production development is probable.

The generalized Hurwitz criterion is expedient to be used in the process of long-term design of enterprises when data of previous comparisons are of disputable nature.

Thus, the research proposes to apply decision-making criteria to design mining operations. Use of the criteria makes it possible to put uncertainty away, and evaluate production risks. However, determination of Savage criterion and the generalized Hurwitz criterion is rather labour-intensive procedure since one should sort alternatives, compare success value with maximal value etc. Institute of Physics of Mining Processes of the National Academy of Science of Ukraine has developed applicable software - Kritery.v2_2019 Program (Fig. 4).

As Figure 4 demonstrates, option 3 will be optimal; thus, the software helps obtain decisive answer.

The program makes it possible to analyze simultaneously up to 1000 options and 1000 scenarios, and run a report according to the analysis data. Moreover, the user obtains the interpreted result. Application of the approach together with the developed software affords an opportunity of production scheduling.

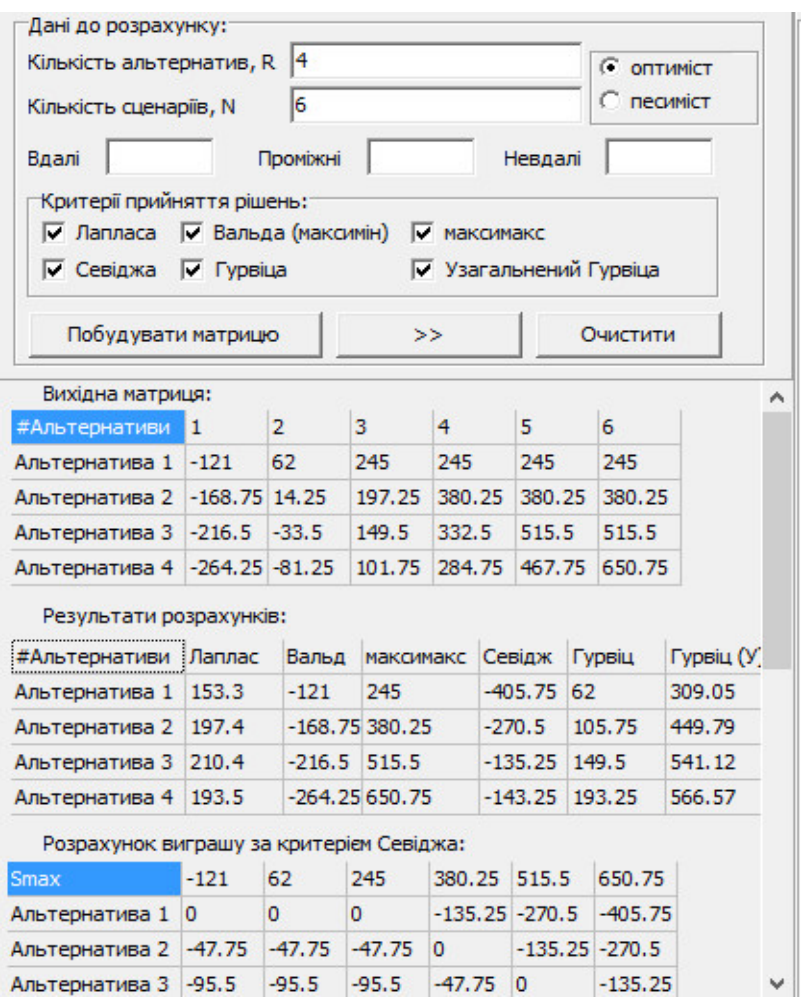

Figure 4. Work window of Kritery.v2_2019

Decision-making trees are also used to solve the current problems. The idea is as follows: the whole cycle is represented in the form of a graph where stage corresponds to vertices and the current solution corresponds to the graph branches (Hrinov \& Khorolskyi, 2018). In such a way, constant production monitoring takes place.

Irrespective of the fact what mining task is implemented, and what tools of decision-making theory are applied, they are united by a common approach. Idea of the approach is in a graph process representation, and its further formalization as a network model and optimization. Applicable software is proposed to implement the approaches.

\section{CONCLUSIONS}

The idea of mining production scheduling is to reduce cost as well as pay-off period. That can be achieved owing to optimization of operation schedules and parameters; moreover, it is required to determine rational output.

Approaches of decision-making theory have been proposed for mining production scheduling. The approaches involve use of trees, decision-making criteria, and scenario analysis. Irrespective of the fact, what tool is used, there is a common approach when operation schedule is represented as a network model. The shortest route within the network model corresponds to optimal solution.

Application area of decision-making criteria under uncertainty conditions has been proposed and substantiated to determine rational output. The above will help minimize loss, and maximize the planned profit. For instance, Wald criterion should be applied while estimating a situation with the worst scenario. Assume, that it is required to estimate loss when equipment is not put into operation; i.e. the equipment has been purchased but the activities are not provided. At the same time, maximax 
criterion makes it possible to estimate value of success in terms of the best scenario. For instance, mining and geological conditions are favourable; factors, limiting equipment efficiency, are not available; and the mined coal is in demand. The use of the applicable software helps introduce the described approaches into mining production.

\section{ACKNOWLEDGEMENTS}

The study has been carried out within the framework of research project of the National Academy Sciences of Ukraine for young scientists "Resource-saving techniques to support mine workings under the complex hydrogeological conditions"; Agreement \#29-04/06-2019; official registration $\# 0119 \mathrm{U} 102370$.

\section{REFERENCES}

Ataei, M., Jamshidi, M., Sereshki, F., \& Jalali, I. (2008). Mining method selection by AHP approach. Journal of the Southern African Institute of Mining and Metallurgy, 108(12), 741-749.

Bogdanovic, D., Nikolic, D., \& Ilic, I. (2012). Mining method selection by integrated AHP and PROMETHEE method. Anais da Academia Brasileira de Ciências, 84(1), 219-233. https://doi.org/10.1590/S0001-37652012000100023

Bondarenko, V., Kovalevs'ka, I., \& Ganushevych, K. (2014). Progressive technologies of coal, coalbed methane, and ores mining. London, United Kingdom: CRC Press, Taylor \& Francis Group. https://doi.org/10.1201/b17547

Goodfellow, R., \& Dimitrakopoulos, R. (2017). Simultaneous stochastic optimization of mining complexes and mineral value chains. Mathematical Geosciences, 49(3), 341-360. https://doi.org/10.1007/s11004-017-9680-3

Gorova, A., Pavlychenko, A., Borysovs'ka, O., \& Krups'ka, L. (2013). The development of methodology for assessment of environmental risk degree in mining regions. Annual ScientificTechnical Collection - Mining of Mineral Deposit, 207-209. https://doi.org/10.1201/b16354-38

Hoseinie, S.H. (2011). Modeling and simulation of drum shearers reliability at mechanized longwall mines. $\mathrm{PhD}$ Thesis. Shahrood, Iran.

Hrinov, V., \& Khorolskyi, A. (2018). Improving the process of coal extraction based on the parameter optimization of mining equipment. E3S Web of Conferences, (60), 00017. https://doi.org/10.1051/e3sconf/20186000017

Iphar, M., \& Alpay, S. (2018) A mobile application based on multi-criteria decision-making methods for underground mining method selection. International Journal of Mining, Reclamation and Environment, 126(3), 69-77. https://doi.org/10.1080/17480930.2018.1467655

Kalybekov, T., Rysbekov, K.B., Toktarov, A.A., \& Otarbaev, O.M. (2019). Underground mine planning with regard to preparedness of mineral reserves. Mining Informational and Analytical Bulletin, (5), 34-43.

Kalybekov, T., Sandibekov, M., Rysbekov, K, \& Zhakypbek, Y. (2019). Substantiation of ways to reclaim the space of the previously mined-out quarries for the recreational purposes. E3S Web of Conference. Article in press.

Kazakidis, V. (2010). Planning for flexibility in underground mine production systems. Technical papers. Advances in Futures and Options Research, (4), 153-164.

Khomenko, O., Kononenko, M., Myronova, I., \& Sudakov, A. (2018). Increasing ecological safety during underground mining of iron-ore deposits. Naukovyi Visnyk Natsionalnoho Hirnychoho Universytetu, (2), 29-38. https://doi.org/10.29202/nvngu/2018-2/3
Khomenko, O., Kononenko, M., \& Lyashenko, V. (2019). Safe mining of granites at the manganese ore deposits of Ukraine. Bezopastnost' Truda v Promyshlennosti, (1), 53-61. https://doi.org/61. 10.24000/0409-2961-2019-1-53-61

Li, P., Tan, Z., Yan, L., \& Deng, K. (2011). Time series prediction of mining subsidence based on a SVM. Mining Science and Technology (China), 21(4), 557-562. https://doi.org/10.1016/j.mstc.2011.02.025

Mahase, M.J., Musingwini, C., \& Nhleko, A.S. (2016). A survey of applications of multi-criteria decision analysis methods in mine planning and related case studies. Journal of the Southern African Institute of Mining and Metallurgy, 116(11), 1051-1056.

https://doi.org/10.17159/2411-9717/2016/v116n11a7

Mamaikin, O., Sotskov, V., Demchenko, Y., \& Prykhorchuk, O. (2018). Productive flows control in coal mines under the condition of diversification of production. E3S Web of Conferences, (60), 00008.

https://doi.org/10.1051/e3sconf/20186000008

Nachbaur, A., \& Rohmer, J. (2011). Managing expertinformation uncertainties for assessing collapse susceptibility of abandoned underground structures. Engineering Geology, 123(3), 166-178. https://doi.org/10.1016/j.enggeo.2011.07.007

Nickel, C., Knight, C., Langille, A., \& Godwin, A. (2019). How much practice is required to reduce performance variability in a virtual reality mining simulator? Safety, 5(2), 18. https://doi.org/10.3390/safety5020018

Petlovanyi, M.V., \& Medianyk, V.Y. (2018). Assessment of coal mine waste dumps development priority. Scientific Bulletin of National Mining University, (4), 28-35. https://doi.org/10.29202/nvngu/2018-4/3

Petlovanyi, M.V., Lozynskyi, V.H., Saik, P.B., \& Sai, K.S. (2018). Modern experience of low-coal seams underground mining in Ukraine. International Journal of Mining Science and Technology, 28(6), 917-923.

https://doi.org/10.1016/j.ijmst.2018.05.014

Pivnyak, G., Dychkovskyi, R., Smirnov, A., \& Cherednichenko, Y. (2013). Some aspects on the software simulation implementation in thin coal seams mining. Energy Efficiency Improvement of Geotechnical Systems, 1-10. https://doi.org/10.1201/b16355-2

Rahal, D., Smith, M., Van Hout, G., \& Von Johannides, A. (2003). The use of mixed integer linear programming for long-term scheduling in block caving mines. In Proceedings of the $31^{\text {st }}$ International APCOM Symposium (pp. 123-131). Cape Town, South Africa.

Salli, S., Pochepov, V., \& Mamaykin, O. (2014). Theoretical aspects of the potential technological schemes evaluation and their susceptibility to innovations. Progressive Technologies of Coal, Coalbed Methane, and Ores Mining, 479-483. https://doi.org/10.1201/b17547-81

Sant'Anna, Â.M.O. (2015). Framework of decision in data modeling for quality improvement. The TQM Journal, 27(1), 135-149. https://doi.org/10.1108/TQM-06-2013-0066

Schniederjans, M., Hamaker, J., \& Schniederjans, A. (2010). Information technology investment: Decision-making methodology. Singapore: World Scientific Pub Co Inc.

Sotskov, V., Podvyhina, O., Dereviahina, N., \& Malashkevych, D. (2018). Substantiating the criteria for applying selective excavation of coal deposits in the Western Donbass. Journal of Geology, Geography and Geoecology, 26(1), 158-164.

https://doi.org/10.15421/111817

Taneja, P., Ligteringen, H., \& Walker, W.E. (2012). Flexibility in port planning and design. European Journal of Transport and Infrastructure Research, 12(1), 66-87. https://doi.org/10.18757/ejtir.2012.12.1.2950 
Tulabandhula, T., \& Rudin, C. (2013). Machine learning with operational costs. The Journal of Machine Learning Research, 14(1), 1989-2028.

Vagonova, O.G., \& Volosheniuk, V.V. (2012). Mining enterprises' economic strategies as derivatives of nature management in the system of social relations. Naukovyi Visnyk Natsionalnoho Hirnychoho Universytetu, (2), 127-134.

Vujić, S. (2011). Multiattributive prediction of terrain stability above underground mining operations. Yugoslav Journal of Operations Research, 21(2), 275-291.

https://doi.org/10.2298/YJOR1102275V
Wang, Ch., Tu, Sh., Zhang, L., Yang, Q., \& Tu, H. (2015). Auxiliary transportation mode in a fully-mechanized face in a nearly horizontal thin coal seam. International Journal of Mining Science and Technology, 25(6), 963-968. https://doi.org/10.1016/j.ijmst.2015.09.013

Yu, S., \& Gao, S. (2016). A dynamic programming model for environmental investment decision-making in coal mining. Applied Energy, (166), 273-281.

https://doi.org/10.1016/j.apenergy.2015.09.099

\section{МОДЕЛІ ТА МЕТОДИ ПРИЙНЯТТЯ РІШЕНЬ ДЛЯ УПРАВЛІННЯ ГІРНИЧИМ ВИРОБНИЦТВОМ}

\section{А. Хорольський, В. Гріньов, О. Мамайкін, Ю. Демченко}

Мета. Розробити новий підхід до проектування гірничого виробництва, який базується на моделях та методах теорії прийняття рішень.

Методика. В роботі застосовано комплексний метод, який включає підходи теорії прийняття рішень. Для стратегічного планування діяльності запропоновано досліджувати сценарії розвитку виробництва, для визначення раціонального рівня виробництва - критерії прийняття рішень в умовах невизначеності, а також дерева прийняття рішень для поточного управління.

Результати. Виявлено, що процес проектування гірничого виробництва має детермінований характер, який демонструє зміну “станів природи” залежно від прийнятих рішень. Суть проектування гірничого виробництва зводиться до послідовного зменшення невизначеності шляхом дослідження сценаріїв виробництва та виключення несприятливих альтернатив. Оперативне управління здійснюється шляхом побудови дерев рішень та оптимізації параметрів експлуатації. Представлення множин раціональних типів обладнання, сценаріїв розвитку подій та порівняння їх за критеріями прийняття рішень дозволяє визначити раціональний рівень видобутку виймальної дільниці і знизити витрати на придбання та обслуговування обладнання, при цьому враховуються обмежувальні фактори, які впливають на величину очікуваного видобутку. Послідовне порівняння альтернатив дозволяє встановити поле прийнятних рішень для різних сценаріїв розвитку виробництва.

Наукова новизна. Для управління гірничим виробництвом запропоновано підходи теорії прийняття рішень, які включають застосування дерев рішень, критеріїв прийняття рішень та аналіз сценаріїв, котрі базуються на представленні технологічного процесу у вигляді мережевої моделі, в якій найкоротший маршрут відповідає оптимальному рішенню.

Практична значимість. Розроблена система прийняття рішень, дозволяє оптимізувати параметри експлуатації, знизити собівартість видобутку, вибрати структуру технологічних зв'язків з заданим рівнем продуктивності. Описані в роботі підходи можуть бути використані як на стадії проектування очисного забою так і в процесі експлуатації родовища корисних копалин. Особливу увагу приділено розробці програмного забезпечення для впровадження описаних підходів у виробництво.

Ключові слова: виробництво, оптимізація, ефективність, програмне забезпечення, критерій

\section{МОДЕЛИ И МЕТОДЫ ПРИНЯТИЯ РЕШЕНИЙ ДЛЯ УПРАВЛЕНИЯ ГОРНЫМ ПРОИЗВОДСТВОМ}

\section{А. Хорольский, В. Гринев, А. Мамайкин, Ю. Демченко}

Цель. Разработать новый подход к проектированию горного производства, который базируется на моделях и методах теории принятия решений.

Методика. В работе использован комплексный метод, который включает подходы теории принятия решений. Для стратегического планирования деятельности предложено исследовать сценарии развития производства, для определения рационального уровня производства - критерии принятия решений в условиях неопределенности, а также деревья принятия решений для текущего управления.

Результаты. Установлено, что процесс проектирования горного производства носит детерминированный характер, который отражает изменение “состояний природы” в зависимости от принятых решений. Суть проектирования сводится к последовательному уменьшению неопределенности путем исследования сценариев производства и исключения неблагоприятных альтернатив. Оперативное управление осуществляется посредством построения деревьев решений и оптимизации параметров эксплуатации. Представление множества рациональных типов оборудования, сценариев развития событий та сравнение их по критериям принятия решений позволяет определить рациональный уровень добычи очистного участка и снизить затраты на приобретение и обслуживание оборудования, при этом учитываются ограничивающие факторы, которые влияют на величину ожидаемой прибыли. Последовательное сравнение альтернатив позволяет установить поле приемлемых решений для разных сценариев развития производства.

Научная новизна. Для управления горным производством предложены подходы теории принятия решений, которые включают применения деревьев, критериев принятия решений и анализ сценариев, основанных на представлении технологического процесса в виде сетевой модели, где кратчайший маршрут соответствует оптимальному решению. 
Практическая значимость. Разработана система поддержки принятия решений, которая позволит оптимизировать параметры эксплуатации, снизить себестоимость добычи, выбрать структуру технологических взаимосвязей с заданным уровнем производительности. Описанные в работе подходы могут быть использованы как на стадии проектирования очистного забоя, так и в процессе эксплуатации месторождения полезных ископаемых. Особое внимание уделено разработке программного обеспечения для внедрения описанных подходов в горное дело.

Ключевые слова: производство, оптимизачия, эффективность, программное обеспечение, критерій

\section{ARTICLE INFO}

Received: 5 March 2019

Accepted: 15 October 2019

Available online: 5 November 2019

\section{ABOUT AUTHORS}

Andrii Khorolskyi, Candidate of Technical Sciences, Researcher of the Laboratory of Mining Problems, Institute for Physics of Mining Processes of the National Academy of Sciences of Ukraine, 15 Simferopolska St, 49005, Dnipro, Ukraine. E-mail: andreykh918@gmail.com

Volodymyr Hrinov, Doctor of Technical Sciences, Head of the Laboratory of Mining Problems, Institute for Physics of Mining Processes of the National Academy of Sciences of Ukraine, 15 Simferopolska St, 49005, Dnipro, Ukraine. E-mail: grinevv@ukr.net

Oleksandr Mamaikin, Candidate of Technical Sciences, Associate Professor of the Department of Mining Engineering and Education, Dnipro University of Technology, 19 Yavornytskoho Ave., 49005, Dnipro, Ukraine. E-mail: mamaykin@yahoo.com

Yurii Demchenko, Candidate of Technical Sciences, Associate Professor of the Department of Mining Engineering and Education, Dnipro University of Technology, 19 Yavornytskoho Ave., 49005, Dnipro, Ukraine. E-mail: dem.yu@,nmu.org.ua 